\title{
QUANTITATIVE RELATIONSHIPS BETWEEN BLOOD AND URINE KETONE LEVELS IN DIABETIC KETOSIS
}

\author{
BY HELEN EASTMAN MARTIN AND ARNE N. WICK \\ (From the Departments of Physiology and Medicine of the University of Southern California, \\ and the Department of Medicine of the Los Angeles General Hospital, Los Angeles, \\ and the Scripps Metabolic Clinic, La Jolla, California)
}

(Received for publication September 17, 1942)

In the study of ketosis in diabetic patients, certain problems have gone largely unanswered due to the lack of sufficiently accurate methods for blood ketone determinations. With the development of blood ketone methods accurate at low as well as high blood concentrations, it has been possible to study the problems of (1) the renal threshold for the ketone bodies, and (2) the quantitative relationship between the urinary ketone excretion and the blood ketone level.

The studies to be presented summarize the results obtained on (1) 13 diabetic patients in mild ketosis, produced by withdrawing insulin for 12 to 24 hours, a ketogenic diet for 12 to 24 hours, or a combination of a ketogenic diet and insulin withdrawal; and (2) 7 patients entering the Los Angeles County Hospital in moderate to severe ketosis (several in diabetic "coma"). In both types of patients, after initial levels of blood and urine ketone bodies were obtained, insulin and fluids were given as required by the individual case, and blood and urine ketone levels were followed until ketosis, as indicated by the qualitative urinary acetone test (modified Lange test), disappeared. The blood ketones ${ }^{1}$ were determined by the Barnes-Wick (1) method, and the urine ketones by the Van Slyke (2) gravimetric method in most instances.

Table I summarizes the results obtained in the diabetic patients in mild ketosis, and Table II the results in patients in moderate to severe ketosis. Figures 1 and 2 give the clinical course, during therapy, of two of the most completely studied cases, one in mild ketosis, the other in severe ketosis. These are patients " $\mathrm{Ha}$ " and "Wi," from Tables I and II, respectively. The figures illustrate how the data listed in the tables were obtained.

1 Total blood and urine ketones calculated as beta-hydroxybutyric acid (1).
From the analysis of the data given in these tables and figures, certain facts are apparent. In Table I (record of patients with blood ketone levels between 1 and $30 \mathrm{mgm}$. per cent), it is seen that even with very low blood ketone levels ( 5 to $10 \mathrm{mgm}$. per cent) small amounts of the ketone bodies appeared in the urine. This indicates that the absolute renal threshold for the ketone bodies in diabetic patients is very lowunder $10 \mathrm{mgm}$. per cent-in the majority of cases. While it is evident that the threshold for the ketone bodies is very low in diabetic patients, relatively small amounts appeared in the urine, less than $100 \mathrm{mgm}$. per hour, until blood levels over $20 \mathrm{mgm}$. per cent are reached. This gives a ratio under 10 for

$$
\frac{\text { urine excretion mgm. per hour }}{\text { blood ketones mgms. per cent }}
$$

in 10 of the patients listed in Table I. In one patient ("P"), all the ratios were under 10 , with one exception, where there was a marked increase in urine output per hour. In two patients ("Ho" and "St"), there were much higher ratios. Certain variations in the ratios at low blood levels can be explained on the basis of marked variations in urinary output per hour.

The great increase in urinary ketone excretion per hour with blood ketone levels over $20 \mathrm{mgm}$. per cent is seen in Table II (blood ketone levels from 35 to $150+$ mgm. per cent). The amount of urine ketones excreted per hour at comparable blood levels varied greatly from patient to patient. As the amount of the urinary ketone excretion is very small as contrasted to the amount utilized (3), this may partially explain this difference. These results in patients in moderate to severe ketosis indicate a complex relationship between the blood ketone level and the urinary ketone output per hour. When the urinary ketone output per hour is charted against the blood level, a 
TABLE I

Ketone excretion in mild ketosis

\begin{tabular}{|c|c|c|c|c|c|}
\hline Patient & Time & Urine volume & Urine ketones* & $\begin{array}{l}\text { Urine ketones } \mathrm{mgm} \text {. per hour } \\
\text { Blood ketones } \mathrm{mgm} \text {. per cent }\end{array}$ & Blood ketones \\
\hline 1. " $\mathrm{Ha} " \dagger$ & $\begin{array}{c}\text { minutes } \\
97 \\
86 \\
43 \\
52\end{array}$ & $\begin{array}{c}\text { cc. per hour } \\
414 \\
1,150 \\
1,310 \\
559\end{array}$ & $\begin{array}{c}\text { mgm. per hour } \\
101 \\
58 \\
25 \\
12.9\end{array}$ & $\begin{array}{l}3.4 \\
3.5 \\
1.6 \\
1.0\end{array}$ & $\begin{array}{c}\text { mgm. per cent } \\
30 \\
16.4 \\
15.5 \\
12.8\end{array}$ \\
\hline 2. "P" $\dagger$ & $\begin{array}{r}166 \\
192 \\
55 \\
40\end{array}$ & $\begin{array}{l}123 \\
106 \\
933 \\
630\end{array}$ & $\begin{array}{c}141 \\
80.5 \\
121 \\
18.3\end{array}$ & $\begin{array}{r}7.4 \\
4.5 \\
22.4 \\
4.5\end{array}$ & $\begin{array}{c}19 \\
14.7 \text { to } 21 \\
5.4 \\
4.1\end{array}$ \\
\hline 3. "Du" $\dagger$ & $\begin{array}{l}201 \\
169\end{array}$ & $\begin{array}{r}128 \\
41\end{array}$ & $\begin{array}{l}94 \\
10.2\end{array}$ & $\begin{array}{l}5.9 \\
5.1\end{array}$ & $\begin{array}{r}16 \\
\pm 2\end{array}$ \\
\hline 4. "Ho" & $\begin{array}{r}269 \\
53 \\
70 \\
65\end{array}$ & $\begin{array}{l}118 \\
386 \\
283 \\
328\end{array}$ & $\begin{array}{l}63.7 \\
52 \\
39 \\
42.5\end{array}$ & $\begin{array}{c}3.7 \\
17 \\
13 \\
7.9\end{array}$ & $\begin{array}{l}21 \text { to } 15.8 \text { to } 6.3 \\
3.6 \text { to } 2.4 \\
2.4 \text { to } 3.6 \\
3.6 \text { to } 7.2\end{array}$ \\
\hline 5. "Str" & $\begin{array}{l}55 \\
60\end{array}$ & $\begin{array}{r}71 \\
276\end{array}$ & $\begin{array}{l}32.5 \\
16.4\end{array}$ & $\begin{array}{l}5.7 \\
2.1\end{array}$ & $\begin{array}{l}5.7 \\
7.9\end{array}$ \\
\hline 6. "Hal" & 315 & 210 & 0 & 0 & 8 to 1.2 \\
\hline 7. “D" & $\begin{array}{l}57 \\
60 \\
57 \\
66 \\
51\end{array}$ & $\begin{array}{r}98 \\
110 \\
69 \\
74 \\
94\end{array}$ & $\begin{array}{r}14.4 \\
4.9 \\
6.9 \\
6.3 \\
6.1\end{array}$ & $\begin{array}{l}1.12 \\
0.83 \\
2.7 \\
2.6 \\
3.2\end{array}$ & $\begin{array}{l}12.8 \\
5.8 \text { to } 6 \\
2.9 \text { to } 2.2 \\
1.7 \text { to } 3.1 \\
3.1 \text { to } 0.7\end{array}$ \\
\hline 8. "Si" & $\begin{array}{l}60 \\
60 \\
90\end{array}$ & $\begin{array}{r}38 \\
138 \\
504\end{array}$ & $\begin{array}{c}51 \\
64 \\
0\end{array}$ & $\begin{array}{l}5.8 \\
7.9 \\
0\end{array}$ & $\begin{array}{c}8.8 \\
8.1 \\
4.7 \text { to } 2.4\end{array}$ \\
\hline 9. “N" & $\begin{array}{l}70 \\
60 \\
60 \\
60\end{array}$ & $\begin{array}{r}107 \\
180 \\
162 \\
40\end{array}$ & $\begin{array}{l}55.9 \\
0 \\
0 \\
0\end{array}$ & $\begin{array}{l}6.8 \\
0 \\
0 \\
0\end{array}$ & $\begin{array}{l}8.2 \\
5.3 \\
2.7 \\
1.4\end{array}$ \\
\hline 10. “Q" & 175 & 63 & 0 & o & 7.8 to 3.8 \\
\hline 11. "B" & $\begin{array}{l}56 \\
62 \\
64 \\
56 \\
43\end{array}$ & $\begin{array}{l}115 \\
420 \\
430 \\
573 \\
725\end{array}$ & $\begin{array}{c}4.81 \\
11.8 \\
35.7 \\
3.96 \\
0\end{array}$ & $\begin{array}{l}0.8 \\
1.8 \\
3.6 \\
1.59 \\
0\end{array}$ & $\begin{array}{r}6.0 \\
6.6 \\
10.0 \\
2.5 \\
1.7\end{array}$ \\
\hline 12. "Be" & $\begin{array}{r}68 \\
180\end{array}$ & $\begin{array}{r} \pm 242 \\
55\end{array}$ & $\pm \underset{0}{31.5}$ & $\underset{0}{ \pm 6.2}$ & $\begin{array}{l}5.1 \\
4.8\end{array}$ \\
\hline 13. "St" & $\begin{array}{l}60 \\
60 \\
58 \\
62\end{array}$ & $\begin{array}{l}350 \\
370 \\
671 \\
203\end{array}$ & $\begin{array}{l}14.6 \\
24 \\
13 \\
7.5\end{array}$ & $\begin{array}{c}3.4 \\
20 \\
18.5 \\
7.5\end{array}$ & $\begin{array}{l}4.3 \\
1.2 \\
0.7 \\
1.0\end{array}$ \\
\hline
\end{tabular}

* Calculated for time period listed.

† Urine ketones fractionated into beta-hydroxybutyric acid and acetone. Amount listed represents beta-hydroxybutyric acid.

$\ddagger$ Urine ketones represent beta-hydroxybutyric acid. (Mercury precipitate dissolved, distilled and reprecipitated.)

hyperbolic type of curve is obtained (Figure 3patient "St"-Table II). When these data from Figure 3 are expressed as a relationship between blood level and a ratio between urine ketone excretion mgm. per hour and blood ketone level in mgm. per cent, a straight line is obtained, with the point of origin passing through the blood level around $20 \mathrm{mgm}$. per cent (Figure 4). In the 


\section{Course of mild Ketosis, with therapy}

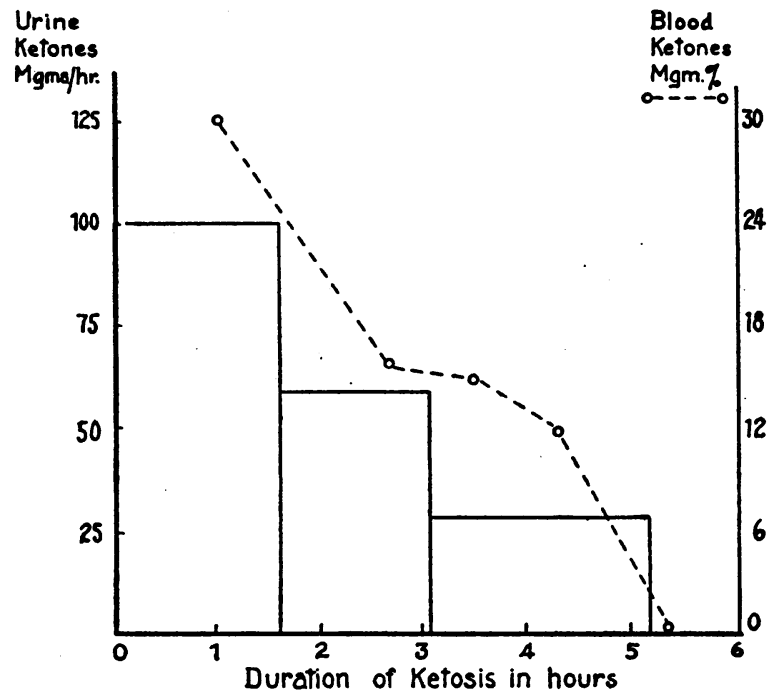

Fig. 1. The Rapid Fall of the Blood Ketone Level and the Small Urinary Ketone Output at Low Blood Ketone Levels (Patient "Ha," Table I)

majority of the cases, a somewhat similar relationship was found, with a marked falling off of the ratio at blood levels under $20 \mathrm{mgm}$. per cent.

Studies in 5 patients included the determination of both acetone (including acetoacetic acid and acetone) and beta-hydroxybutyric acid in the urine, at varying blood levels -2 to $78 \mathrm{mgm}$. per cent. The results are listed in Table III. In patients "Ha" and " $\mathrm{K}$," acetone represented approximately 80 per cent of the ketone bodies in the urine at the lower blood levels. In patient "P," the urinary acetone rose from 11 per cent, at a blood ketone level of $19 \mathrm{mgm}$. per cent, to 41 per cent, at a blood ketone level of $2.9 \mathrm{mgm}$. per cent. In patient " $B$," the urinary acetone rose from 42 to 100 per cent, with corresponding change in blood ketone level from 6 to $1.7 \mathrm{mgm}$. per cent. In patient " $D$," there was only a slight increase in percentage of acetone at the lower blood ketone levels.

In studying the data summarized above, certain other points of interest were noted. In all the patients in moderate to severe ketosis, the carbon dioxide combining power was determined repeatedly and synchronously with the blood ketone determinations. The lack of specific correlation in different patients between the carbon dioxide combining power and the blood ketone level is seen in Table IV. (This reaffirms the previous work of many.) In this table it is seen that one patient with a carbon dioxide combining power of 10 volumes per cent had a blood ketone level of $80 \mathrm{mgm}$. per cent, while another patient with a carbon dioxide combining power of 16 volumes per cent had a blood ketone level over $150 \mathrm{mgm}$. per cent. Since the carbon dioxide combining power is only a measure of the alkali reserve, and this is determined by many factors other than the degree of ketosis in uncontrolled diabetes, it is obvious why the two determinations are not more closely related.

Table $\mathrm{V}$ shows the low urinary ketone output per hour in a patient with uremia and oliguria. In this patient with blood ketone levels over 150 mgm. per cent, 61.7 to $455 \mathrm{mgm}$. per hour were excreted in the urine.

\section{DISCUSSION}

There are few quantitative figures given in the literature on the relationship between blood and urine ketone levels. The impression, however, is given that there is no correlation. As Peters and Van Slyke (4) state: "The relation between blood and urine ketones has not been studied; but the data of Allen, Stillman and Fitz show a peculiar lack of association between the two." In studying the data of these authors (5), it is noted that the total urinary ketone excretion for 24 hours, with varying diets or starvation, is correlated apparently with one or two blood ketone levels. As variations occur during the 24 hours, it is impossible to draw conclusions from their data, although their results do show very small urinary ketone output at low blood ketone levels. Also there are very few references to the renal threshold for the ketone bodies in the literature. The work of Wilder (6) on the injection of beta-hydroxybutyric and acetoacetic acid into dogs, suggested a urinary threshold, since 0.4 gram per $\mathrm{kgm}$. of body weight had to be injected before beta-hydroxybutyric acid appeared in the urine. Briggs and Shaffer (7) conclude from their studies that acetone is a non-threshold substance, and the concentration in the urine parallels the concentration in the blood. These authors, and also Widmark (8), state that under certain conditions acetone can diffuse into the urinary bladder directly from the blood, like alcohol, with- 
TABLE II

Ketone excretion in moderate to severe ketosis

\begin{tabular}{|c|c|c|c|c|c|c|}
\hline Patient & Time & $\begin{array}{c}\text { Urine } \\
\text { volume }\end{array}$ & $\begin{array}{l}\text { Total urine } \\
\text { ketones }\end{array}$ & $\begin{array}{c}\text { Urine } \\
\text { ketones }\end{array}$ & $\frac{\text { Urine ketones } \mathrm{mgm} \text {. per hour }}{\text { Blood ketones mgm. per cent }}$ & $\begin{array}{c}\text { Blood } \\
\text { ketones }\end{array}$ \\
\hline 1. "Wi" & $\begin{array}{c}\text { minutes } \\
240 \\
250 \\
165 \\
260 \\
225 \\
190 \\
170 \\
180 \\
170 \\
85 \\
210\end{array}$ & $\begin{array}{c}\text { cc. per hour } \\
589 \\
444 \\
336 \\
426 \\
613 \\
805 \dagger \\
380 \\
282 \dagger \\
405 \\
494 \\
128\end{array}$ & $\begin{array}{c}\text { mgm. } \\
22,050 \\
18,120 \\
9,000 \\
12,560 \\
9,950 \\
4,630+ \\
1,135 \\
955+ \\
340 \\
0 \\
136\end{array}$ & $\begin{array}{c}\text { mgm. per hour* } \\
5,512 \\
4,350 \\
3,270 \\
2,900 \\
2,650 \\
1,400+ \\
400 \\
318+ \\
120 \\
0 \\
39\end{array}$ & $\begin{array}{l}66.5 \\
58 \\
43.6 \\
39.2 \\
44.2 \\
85.4 \\
\\
\\
9.4 \\
0 \\
10.4\end{array}$ & $\begin{array}{c}\text { mgm. per cent } \\
80 \text { to } 86 \\
75 \\
75 \\
74 \\
60 \\
16.4 \\
\\
12.8 \\
1.3 \text { to } 2.3 \\
2.3 \text { to } 5.2\end{array}$ \\
\hline 2. "St" & $\begin{array}{l}290 \\
110 \\
180 \\
180 \\
175 \\
125\end{array}$ & $\begin{array}{c}370 \\
327 \\
297 \\
+160(?) \\
284 \\
198\end{array}$ & $\begin{array}{r}17,305 \\
2,340 \\
1,322 \\
534 \\
343 \\
77\end{array}$ & $\begin{array}{r}3,580 \\
1,270 \\
440 \\
+178 \\
117 \\
37\end{array}$ & $\begin{array}{r}70.6 \\
30.6 \\
16.8 \\
\pm 7.7 \\
6.4 \\
2.3\end{array}$ & $\begin{array}{c}60 \text { to } 41.5, \text { av. } 50.7 \\
41.5 \\
29.9 \text { to } 22.9 \text {, av. } 26 \\
23.1 \\
18.3 \\
16.2\end{array}$ \\
\hline 3. “K" $\mathrm{K}$ & $\begin{array}{r}240 \\
65 \\
65 \\
57 \\
60\end{array}$ & $\begin{array}{r}272 \\
55 \\
250 \\
137 \\
200\end{array}$ & $\begin{array}{r}3,014 \\
56 \\
116 \\
9 \\
12\end{array}$ & $\begin{array}{r}754 \\
52 \\
107 \\
9 \\
12\end{array}$ & $\begin{array}{l}9.7 \\
0.8 \\
2.1 \\
0.24\end{array}$ & $\begin{array}{l}78 \\
66 \\
51.7 \\
38\end{array}$ \\
\hline 4. "B" & $\begin{array}{r}110 \\
130 \\
120 \\
120 \\
60\end{array}$ & $\begin{array}{l}292 \\
180 \\
285 \\
365 \\
110\end{array}$ & $\begin{array}{r}485 \\
376 \\
237 \\
0 \\
0\end{array}$ & $\begin{array}{r}264 \\
174 \\
119 \\
0 \\
0\end{array}$ & $\begin{array}{l}7.2 \\
5.8 \\
4.9 \\
0 \\
0\end{array}$ & $\begin{array}{l}36.9 \\
29.9 \\
24.3 \\
11.1 \\
10\end{array}$ \\
\hline 5. "G" & $\begin{array}{r}130 \\
50 \\
60 \\
375 \\
140\end{array}$ & $\begin{array}{l}128 \\
516 \\
610 \\
138 \\
178\end{array}$ & $\begin{array}{r}2,710 \\
922 \\
397 \\
311 \\
40\end{array}$ & $\begin{array}{r}1,254 \\
1,106 \\
397 \\
50 \\
17\end{array}$ & $\begin{array}{c}19.6 \\
15.9 \\
3 \\
4\end{array}$ & $\begin{array}{r}64 \\
25 \\
4\end{array}$ \\
\hline 6. "W" & $\begin{array}{l}155 \\
135 \\
115 \\
120 \\
120\end{array}$ & $\begin{array}{c}170 \dagger \\
131 \dagger \\
82 \\
121 \\
21 \dagger\end{array}$ & $\begin{array}{c}618+ \\
158+ \\
98 \\
0 \\
0\end{array}$ & $\begin{array}{c}239+ \\
70+ \\
51 \\
0 \\
0\end{array}$ & $\begin{array}{l}6.6+ \\
2.7+ \\
2.2 \\
0 \\
0\end{array}$ & $\begin{array}{c}36.3 \\
26.9 \text { to } 25.8 \\
22.4 \text { to } 23.5 \\
5.1\end{array}$ \\
\hline 7. “H”\& & $\begin{array}{l}185 \\
135\end{array}$ & $\begin{array}{r}117 \\
53\end{array}$ & $\begin{array}{l}977 \\
330\end{array}$ & $\begin{array}{l}316 \\
147\end{array}$ & & 108 to $150+$ \\
\hline
\end{tabular}

* Calculated for time period listed.

t Some urine lost.

I Urine ketones fractionated into acetone and beta-hydroxybutyric acid. Amount listed represents beta-hydroxybutyric acid.

$\$$ Patient in uremia.

out excretion through the kidneys. Widmark further claims that for acetoacetic acid there is no correlation between the blood and urine curves, indicating secretory activity of the kidney. All this early work, however, is open to the criticism of relatively inaccurate blood methods. Shipley and Long (9) in recent years have established evidence that in the rat, there is a definite renal threshold-between 25 and $30 \mathrm{mgm}$. per cent.
Our results give definite quantitative data concerning the renal threshold for the ketone bodies, and the correlation between blood level and the urinary excretion per hour. The urinary excretion of ketone bodies varies with the blood level, but does not act similarly to such substances as urea. When the urinary ketone output per hour is charted against the blood level, a somewhat hyperbolic type of curve is obtained, with a 


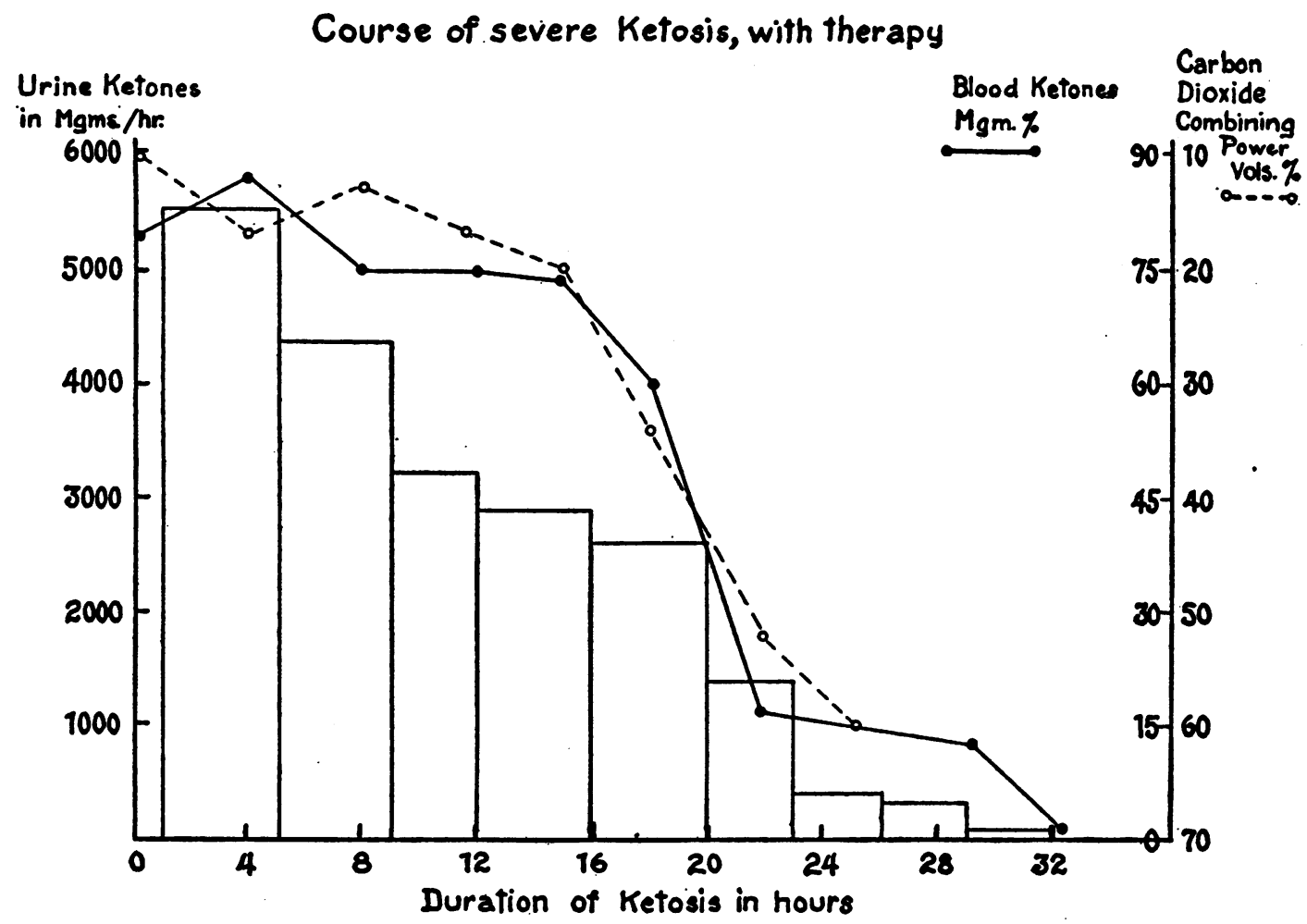

Fig. 2. The Prolonged Period of Severe Ketosis (20 hours) With the Very Large Urinary Ketone Output at the High Blood Ketone levers (Patient "Wi," Table II)

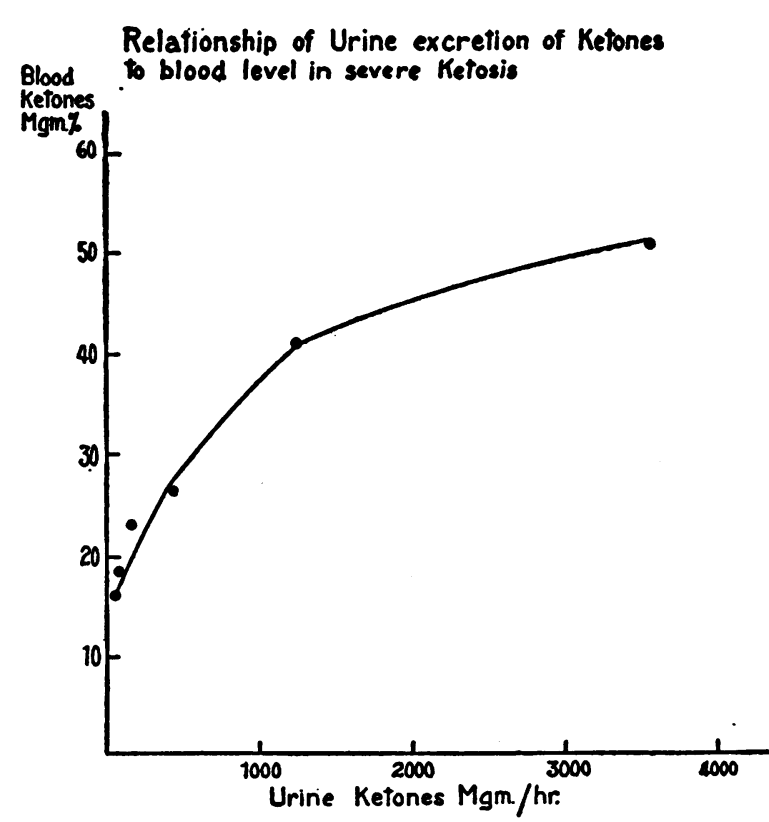

Fig. 3. The Increase in Urinary Ketone Output PER Hour with Rising Blood Ketone Levels (Patient "St," Table II)

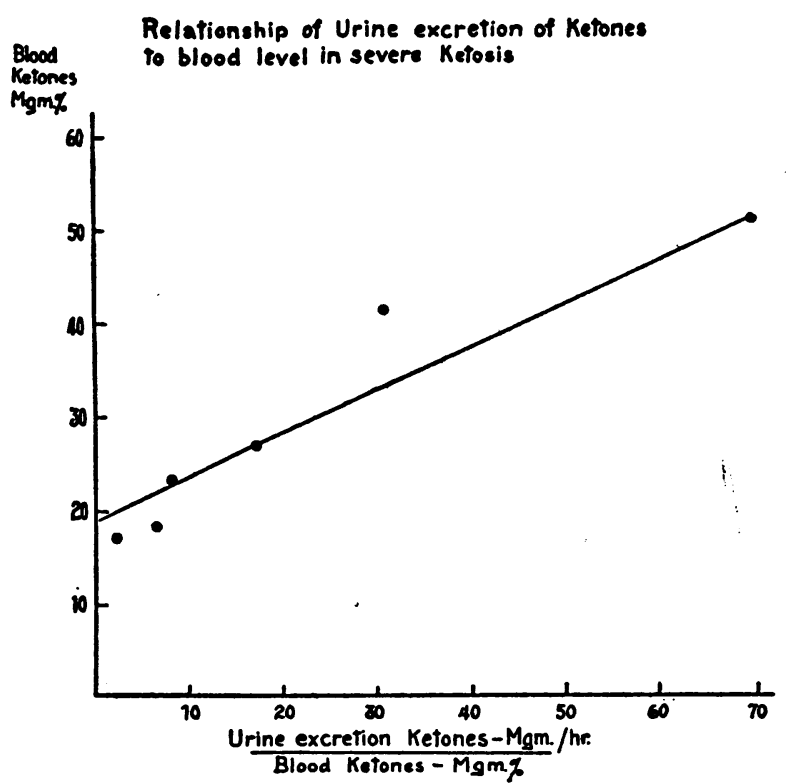

Fig. 4. Expressing the Data frox Figure 3 as a Ratio Between Blood Ketone Levei and the Ratio Between Urine Ketones per Hour and Blood Levei, a Stratght Line Reichtonship is Obtained (Patient "St," Table II) 
TABLE III

Fractionation of urine ketones into beta-hydroxybutyric acid and acetone*

\begin{tabular}{|c|c|c|c|c|c|}
\hline Patient & $\begin{array}{c}\text { Total } \\
\text { acetone } \\
\text { in urine }\end{array}$ & $\begin{array}{c}\text { Total } \\
\text { beta- } \\
\text { hydroxy- } \\
\text { butyric } \\
\text { acid } \\
\text { in urine }\end{array}$ & $\begin{array}{l}\text { Ace- } \\
\text { tone }\end{array}$ & $\begin{array}{l}\text { Beta- } \\
\text { hydroxy- } \\
\text { butyric } \\
\text { acid }\end{array}$ & $\begin{array}{c}\text { Blood } \\
\text { ketones }\end{array}$ \\
\hline 1. "B" & $\begin{array}{c}\text { mgm. } \\
3.1 \\
2.3 \\
9.6 \\
18 \\
3.4 \\
6.8\end{array}$ & $\begin{array}{r}\text { mgm. } \\
4.3 \\
4.5 \\
12.2 \\
38.2 \\
3.7 \\
0\end{array}$ & $\begin{array}{c}\text { per cent } \\
42 \\
33 \\
44 \\
32 \\
48 \\
100\end{array}$ & $\begin{array}{c}\text { per cent } \\
58 \\
67 \\
56 \\
68 \\
52 \\
0\end{array}$ & $\begin{array}{c}\text { mem. per cent } \\
6 \\
6.6 \\
10 \\
2.5 \\
1.7\end{array}$ \\
\hline 2. "K" & $\begin{array}{r}34 \\
35 \\
460 \\
84 \\
34 \\
113 \\
38 \\
68\end{array}$ & $\begin{array}{r}68 \\
385 \\
2,300 \dagger \\
329 \\
56 \\
116 \\
9 \\
12\end{array}$ & $\begin{array}{r}34 \\
8 \\
17 \\
20 \\
37 \\
50 \\
81 \\
85\end{array}$ & $\begin{array}{l}66 \\
92 \\
83 \\
80 \\
63 \\
50 \\
19 \\
15\end{array}$ & $\begin{array}{l}78 \\
75 \\
78 \\
66 \\
51 \\
38\end{array}$ \\
\hline 3. " $\mathrm{Ha} "$ & $\begin{array}{l}80 \\
84 \\
47 \\
65 \\
41.7 \\
78\end{array}$ & $\begin{array}{c}163 \\
76 \\
7.1 \\
17.9 \\
17.2 \\
28.9\end{array}$ & $\begin{array}{l}33 \\
53 \\
87 \\
78 \\
79 \\
73\end{array}$ & $\begin{array}{l}67 \\
47 \\
13 \\
22 \\
21 \\
27\end{array}$ & $\begin{array}{l}30 \\
16.4 \\
15.5 \\
12.8 \\
0.5\end{array}$ \\
\hline 4. " $P$ " & $\begin{array}{c}48.9 \\
46.9 \\
18 \\
9.5 \\
8.4\end{array}$ & $\begin{array}{c}391 \\
258 \\
85 \\
26.2 \\
12.2\end{array}$ & $\begin{array}{l}11 \\
15.4 \\
17.4 \\
27 \\
41\end{array}$ & $\begin{array}{l}89 \\
84.6 \\
82.6 \\
73 \\
59\end{array}$ & $\begin{array}{l}19 \\
21 \text { to } 14.7 \\
5.4 \\
4.1 \\
2.9\end{array}$ \\
\hline 5. “D" & $\begin{array}{r}23.4 \\
48.1 \\
5.3\end{array}$ & $\begin{array}{r}270 \\
314 \\
28.8\end{array}$ & $\begin{array}{c}8 \\
13.3 \\
15.5\end{array}$ & $\begin{array}{l}92 \\
86.7 \\
84.5\end{array}$ & $\begin{array}{r}16 \\
2\end{array}$ \\
\hline
\end{tabular}

* Acetone represents acetoacetic acid and acetone.

$\dagger$ Bladder not completely emptied before, catheter inserted at this point.
TABLE IV

Lack of correlation between carbon dioxide combining power and blood ketone level

\begin{tabular}{cc}
\hline $\begin{array}{c}\text { Blood carbon dioxide } \\
\text { combining power }\end{array}$ & Blood ketones \\
\hline rolumes per cent & $\begin{array}{c}\text { mgm. per cens } \\
10\end{array}$ \\
13 & 75 \\
14 & 64 \\
16 & $150+$ \\
17 & $86,78,30$ \\
20 & 75,24 \\
23 & 37 \\
27 & 75 \\
28 & 69,11 \\
34 & $51,60,25$ \\
44 & 10 \\
46 & 26
\end{tabular}

marked fall in output with blood levels under $2 \overrightarrow{0}$ to $30 \mathrm{mgm}$. per cent. (The exact levels vary from patient to patient.) In contrast, when urea excretion per hour is plotted against the blood urea level, a straight line passing through the point of origin is obtained. When the relationship between blood and urine ketones is expressed as a ratio: $\frac{\text { urinary ketones } \mathrm{mgm} \text {. per hour }}{\text { blood ketones mgms. per cent }}$ the fact that the ketone bodies are threshold substances is clearly demonstrated, as there is a striking change in the ratio at low and high blood concentrations. This, again, is in distinct contrast to threshold substances, like urea, where the threshold is proportional to the blood concentration. Addis and Drury $(10,11)$ showed with urea "That under certain special conditions the rate of urea excre-

TABLE $\mathbf{v}$

Ketone excretion in patient with oliguria and arotemia

\begin{tabular}{|c|c|c|c|c|c|c|}
\hline Time & Blood ketones & Urine ketones & $\begin{array}{c}\text { Urine } \\
\text { volume }\end{array}$ & Blood sugar & $\mathrm{CO}_{2}$ C.P. & Fluid intake \\
\hline $\begin{array}{l}\text { 9:30 A.M. } \\
10: 10 \\
10: 10 \text { to } 11: 25 \\
10: 40 \\
11: 25 \text { to } 12: 30 \\
11: 45 \\
12: 15 \text { P.M. } \\
12: 30 \\
12: 30 \text { to } 2: 30 \\
1: 33 \\
2: 30 \text { to } 4: 45 \\
3: 42 \\
4: 45 \\
5: 55\end{array}$ & $\begin{array}{l}150+ \\
108 \\
69 \\
39\end{array}$ & $\begin{array}{c}\text { mgm. per hour* } \\
? \\
61.7\end{array}$ & \begin{tabular}{|c|} 
cc. per hour \\
8 \\
55
\end{tabular} & $\begin{array}{l}\text { mgm. per cent } \\
930 \text { (N.P.N. }=80 \\
\text { mgm. per cent) }\end{array}$ & $\begin{array}{l}\text { oolumes per centt } \\
16\end{array}$ & $\begin{array}{l}1000 \text { cc. } \text { N.S. i.v. } \\
1000 \text { cc. } \text { N.S. i.v. } \\
1000 \text { cc. N.S. i.v. } \\
1000 \text { cc. N.S. subcut. } \\
1000 \text { cc. M/6 sodium } \\
\text { lactate }\end{array}$ \\
\hline
\end{tabular}

* All urines gave a positive qualitative acetone test.

$+\mathrm{CO}_{2}$ C.P. - carbon dioxide combining power.

¥ Just at death.
N.P.N.-non-protein nitrogen.

N.S.-normal saline.

i.v.-intravenously.

subcut. - subcutaneously.

M/6-sixth molar. 
tion becomes directly proportional to the blood urea concentration, so that in any one individual the ratio: $\frac{\text { urea in } 1 \text { hour's urine }}{\text { urea in } 100 \mathrm{cc} \text {. of blood }}$ is a constant with only narrow limits of variation, over a wide range of blood urea concentrations." The fact that the percentage of acetone (and hence acetoacetic acid) increased proportionally to beta-hydroxybutyric acid at a very low blood level suggests that these substances are non-threshold substances, and would account for the majority of ketone bodies found in the urine under blood levels of $20 \mathrm{mgm}$. per cent. This is further evidence that beta-hydroxybutyric acid is a threshold substance. It thus appears to belong to the group of threshold substances, and behaves similarly to such electrolytes as chlorides (12), substances with "fixed" thresholds.

These results are of significance clinically. The qualitative urinary acetone test, in the majority of cases, roughly paralleled the quantitative total urinary ketone output. The results in one patient with uremia and oliguria suggest, however, that such a gauge of blood level, i.e. urinary acetone, can be used only in the presence of adequate renal function. This has been suggested by others (13, 14), although Briggs (15) claims that it is impossible to have ketone bodies in the blood and not in the urine, due to diffusion directly from the blood to urine in the urinary bladder.

\section{SUMMARY}

Studies on 20 diabetics in mild and severe ketosis have shown:

1. The low urinary output of ketone bodies (less than $100 \mathrm{mgm}$. per hour) with blood ketone levels under $20 \mathrm{mgm}$. per cent. This is probably due largely to the excretion of acetone which appears to be a non-threshold substance.

2. A relationship between blood ketone levels and urinary output:

a. Increased urinary output per hour with rising blood ketone levels.

b. A renal threshold for beta-hydroxybutyric acid over $20 \mathrm{mgm}$. per cent.

3. Impaired urinary excretion with renal failure.

4. A lack of correlation between the blood ketone level and the carbon dioxide combining power.

Appreciation is expressed by the authors to Dr. D. R. Drury and Dr. Eaton MacKay for criticism and help, and to Mr. Anthony Muff for technical assistance.

\section{BIBLIOGRAPHY}

1. Barnes, R. H., and Wick, A. N., A method for the determination of blood acetone bodies. J. Biol. Chem., 1939, 131, 413.

2. Van Slyke, D. D., The determination of B-hydroxybutyric acid, acetoacetic acid, and acetone in urine. J. Biol. Chem., 1917, 32, 455.

3. Barnes, R. H., and Drury, D. R., Utilization of ketone bodies by the tissues in ketosis. Proc. Soc. Exper. Biol. and Med., 1937, 36, 350.

4. Peters, J. P., and Van Slyke, D. D., Quantitative Clinical Chemistry. Vol. I-Interpretations. Williams and Wilkins, Baltimore, 1931.

5. Allen, F. M., Stillman, E., and Fitz, R., Total dietary regulation in the treatment of diabetes. Monographs of the Rockefeller Institute for Medical Research, New York, 1919.

6. Wilder, R. M., Intravenous injections of Beta-hydroxybutyric and acetoacetic acids. J. Biol. Chem., 1917, 31, 59.

7. Briggs, A. P., and Shaffer, P. A., The excretion of acetone from the lungs. J. Biol. Chem., 1921, 48, 413.

8. Widmark, E. M. P., Studies in the acetone concentration in blood, urine, and alveolar air. I. The passage of acetone and aceto-acetic acid into the urine. Biochem. J., 1920, 14, 364.

9. Shipley, R. A., and Long, C. N. H., Studies on ketogenic activity of anterior pituitary; relation of ketonaemia to ketonuria in rat; method for assay of ketogenic activity; nature of ketogenic principle. Biochem. J., 1938, 32, 2242.

10. Addis, T., and Drury, D. R., The rate of urea excretion. The effect of changes in blood urea concentration on the rate of urea excretion. J. Biol. Chem., 1923, 55, 105.

11. Drury, D. R., The effect of very high blood urea concentrations on the rate of urea excretion. J. Biol. Chem., 1923, 55, 113.

12. MacKay, E. M., and MacKay, L. L., Relation of the urine chloride rate to the plasma chloride concentration before and after administration of sodium chloride. Am. J. Physiol., 1936, 115, 455.

13. Richardson, R., Diabetic acidosis with negative reaction for diacetic acid in the urine. M. Clin. North America, 1932, 16, 257.

14. Labbé, M., and Boulin, R., Coma diabétique sans réaction de Gerhardt. Bull. et mém. Soc. Méd. d. hôp. de Paris, 1933, 49, 313.

15. Briggs, A. P., The management of diabetes as controlled by tests of acetone in expired air. J. Lab. and Clin. Med., 1940, 25, 603. 